\title{
Is locked compressive intramedullary nailing for adult humerus shaft fractures advantageous?
}

\author{
Erişkin humerus cisim kırıklarında kilitli kompresif intramedüller çivileme avantajı mıdır?
}

\author{
Fatih Duygun, MD, Cengiz Aldemir, MD \\ Department of Orthopedics and Traumatology, Health Sciences University, Antalya Training and Research Hospital, Antalya, Turkey
}

\begin{abstract}
Objectives: This study aims to evaluate the radiological and functional outcomes of locked compressive intramedullary nailing (IMN) cases in adult humerus shaft fractures.

Patients and methods: A total of 24 patients (12 males, 12 females; mean age 42 years; range 23 to 55 years) with humerus fractures were treated with locked compressive IMN at the Orthopaedics and Traumatology Clinic, Antalya Training and Research Hospital between December 2009 and March 2015. Fluoroscopy was used only to check fracture reduction before the reaming procedure. Of the patients, closed IMN was performed in 21 , while open reduction was performed in three. Lock screws were locked without fluoroscopy in all patients. Of the patients in whom open reduction was performed, radial nerve lesion developed in one. Anteroposterior and lateral graphs of all patients were taken postoperatively. Fracture union was assessed according to existence of the fracture line and the callus tissue in the anteroposterior and lateral graphs. The Constant-Murley scoring system was used for functional evaluation. The mean follow-up period was 24 months (range 12 to 72 months). Finite element analysis was performed for the stress distribution on fracture site.
\end{abstract}

Results: Radiological fracture union was achieved in all patients at mean 14.8 weeks (range 12 to 17 weeks). The Constant-Murley score was mean 90 (range 72 to 100). There was a statistically significant, negative and strong correlation between union period and the Constant-Murley score $(\mathrm{r}=-0.78, \mathrm{p}<0.001)$. In one patient who developed postoperative radial nerve symptoms, all functions were regained in fourth month. No infection occurred in any patient. In two patients, tip of the nail remained high. Of these patients, one developed impingement findings, and the other patient had no problems.

Conclusion: Treatment of humerus shaft fractures with locked compressive IMN provides sufficient fixation and early movement opportunity in the shoulder and elbow joints, and gives satisfactory radiological and functional results.

Keywords: Compression; humerus fracture; intramedullary nail; union.

\section{Öz}

Amaç: Bu çalışmada erişkin humerus cisim kırıklarında kilitli kompresif intramedüller çivileme (İMÇ) olgularının radyolojik ve fonksiyonel sonuçları değerlendirildi.

Hastalar ve yöntemler: Antalya Eğitim ve Araştırma Hastanesi Ortopedi ve Travmatoloji Kliniğinde Aralık 2009 - Mart 2015 tarihleri arasında humerus kırığı olan toplam 24 hasta (12 erkek, 12 kadın; ort. yaş 42 yıl; dağılım 23-55 yıl) kilitli kompresif çivileme ile tedavi edildi. Floroskopi sadece oyma işlemi öncesi kırık redüksiyonunu kontrol etmek için kullanıldı. Hastaların 21'inde kapalı İMÇ uygulanırken üçünde açık redüksiyon uyguland1. Kilit vidaları tüm hastalarda floroskopisiz olarak kilitlendi. Açık redüksiyon yapılan hastalardan birinde radial sinir lezyonu gelişti. Tüm hastaların ameliyat sonrası ön-arka ve yan grafileri çekildi. Kırık kaynaması ön-arka ve yan grafilerde kırık çizgisinin ve kal dokusunun olup olmamasına göre değerlendirildi. Fonksiyonel değerlendirme için ConstantMurley skorlama sistemi kullanıldı. Ortalama takip süresi 24 ay (dağılım $12-72$ ay) idi. Kırık hattındaki stres dağılımı için sonlu eleman analizi yapıldı.

Bulgular: Tüm hastalarda ortalama 14,8 haftada (dağ 11 m 12-17 hafta) radyolojik kırık kaynaması sağlandı. ConstantMurley skoru ortalama 90 (dağılım 72-100) idi. Kaynama süresi ile Constant-Murley Skoru arasında istatistiksel olarak anlamlı, negatif ve güçlü bir korelasyon vardı $(r=-0,78, p<0,001)$. Ameliyat sonrası radial sinir semptomları gelişen bir hastada dördüncü ayda tüm fonksiyonlar geri döndü. Hiçbir hastada enfeksiyon gelişmedi. İki hastada çivinin ucu yüksek idi. Bu hastalardan birinde sıkışma bulguları oluştu, diğer hastanın herhangi bir problemi yoktu.

Sonuç: Humerus cisim kırıklarının kilitli kompresif İMÇ ile tedavisi yeterli tespit, omuz ve dirsek ekleminde erken hareket imkanı sağlamakta ve tatmin edici radyolojik ve fonksiyonel sonuçlar vermektedir.

Anahtar sözcükler: Kompresyon; humerus kırı̆̆ı; intramedüller çivi; kaynama.

- Received: March 14, 2017 Accepted: June 20, 2017

- Correspondence: Fatih Duygun, MD. Sağlık Bilimleri Üniversitesi, Antalya Eğitim ve Araştırma Hastanesi Ortopedi ve Travmatoloji Anabilim Dalı, 07ı0 Antalya, Turkey. Tel: +90 533 - 7176231 e-mail: fduygun2000@yahoo.com 
Humerus diaphyseal fractures are relatively a frequent type of fractures. Their incidence was reported as approximately 3 to $5 \%$ of all fractures. ${ }^{[1]}$ The majority of these fractures can be treated conservatively. There are many conservative treatment options from shoulder-arm plaster casting to functional braces. As they are easy to apply and results are satisfactory, functional braces are often applied. ${ }^{[2]}$ The complication rates are low with conservative methods. ${ }^{[3]}$

Surgical treatment is required when conservative treatment is not successful, when there are concomitant injuries to the main vascular structures, multi-trauma, open fracture or floating elbow. ${ }^{[3]}$ Plate and screw, intramedullary nailing (IMN) and external fixator can be used as surgical treatments. ${ }^{[3]}$ Fixation with a permanent or temporary external fixator can be applied particularly to protect open fractures from infections. As union rates are high and complication rates are low, the application of plate and screw is still used as the gold standard in surgical treatment. ${ }^{[1,4]}$ Nevertheless, the application of plate and screw to humerus shaft fractures has the disadvantages of relatively more blood loss, radial nerve damage, and greater soft tissue damage..$^{[5]}$

In parallel with the successful results obtained in recent years in femur and tibia fractures, the application of IMN has become more widespread in humerus shaft fractures ${ }^{[6]}$ Despite the advantages of a shorter hospital stay, less blood loss, a more rapid and higher rate of union, the disadvantages of shoulder problems may be observed through the antegrade application. ${ }^{[7]}$ Therefore, in this study, we aimed to evaluate the radiological and functional outcomes of locked compressive IMN cases in adult humerus shaft fractures.

\section{PATIENTS AND METHODS}

The study included 24 patients (12 males, 12 females; mean age 42 years; range 23 to 55 years) with humerus shaft fractures who were treated with locked compressive IMN at the Orthopaedics and Traumatology Clinic, Antalya Training and Research Hospital between December 2009 and March 2015. Of the fractures, 18 were in the right humerus and six were in the left humerus. The localization of the humerus fracture was determined as the mid third in 15 patients, the proximal third in six patients and the distal third in three patients. According to the Arbeitsgemeinschaft für Osteosynthesefragen (AO) classification, 16 patients were evaluated as AO A3, five patients as A1 and three patients as C 3 . All the fractures were closed ones. The study protocol was approved by the Antalya Training and Research
Hospital Ethics Committee. A written informed consent was obtained from each patient. The study was conducted in accordance with the principles of the Declaration of Helsinki.

The mechanisms of injury were traffic accidents in 18 patients and fall from height in six patients. In one patient, there was a concomitant femur fracture and surgery was applied for an isolated humerus fracture in all the other patients. Preoperatively, the vascular and neurological examination results were normal. Closed IMN was applied to 21 of the patients. As closed reduction could not be obtained in three patients, open reduction was performed. In one of these three patients with a fragmented fracture, a radial nerve lesion occurred postoperatively. Compressive IMN was applied to 20 patients where an appropriate position could not be obtained with plaster cast-splint closed reduction in the Emergency Department, and to four patients with the position loss following reduction with conservative methods. The time from trauma to surgery was mean five days (range 1 to 7 days). At one hour preoperatively, $1 \mathrm{~g}$ first-generation cephalosporin was applied intravenously and this was continued for 48 hours.

There was no requirement for the use of wire cerclage or graft in any patient. From day one postoperatively, passive movements were started and in the third week, active movements were initiated. With the exception of three patients with a fragmented fracture, no brace was required.

The mean follow-up period was 24 months (range 12 to 72 months). During follow-up, functional and radiological evaluations were performed (Figures 1, 2a, b, 3). Functional evaluation was performed according to the Constant-Murley scoring system, in which $100-80$ points are evaluated as a very good functional result, $80-60$ as good, $60-40$ as moderate, $40-20$ as poor and $20-0$ as very poor.

A C75 locking compressive humerus nail was used in all patients (Hipokrat, Izmir, Turkey). Under general anesthesia, the patient was placed in the beach-chair position. Following sterile cleaning and draping, a longitudinal skin incision from the lateral point of the acromion extend was performed, centered over the tip of the greater tuberosity. Attention should be paid not to extend the incision more than 4 to $5 \mathrm{~cm}$ in the deltoid muscle to avoid damaging the axillary nerve. The rotator sheath was reached after passing through the deltoid fibers. A small longitudinal split was created in the insertion of the supraspinatus muscle. With awl, the entrance hole was opened, then reduction was provided under 


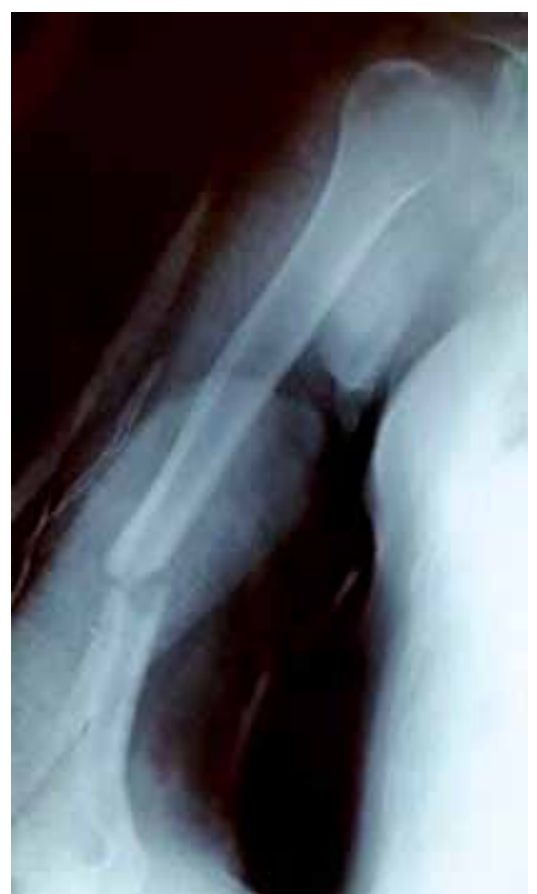

Figure 1. Preoperative radiograph of a 34-year-old male patient.

fluoroscopy and it was reamed starting from the smallest reamer via the guide wire. The appropriate length and thickness of the nails to be used were determined and these were gently inserted with a nail holder. The guides were then placed over the holder for distal locking (Figure 4a, b). Bone alignment and aspiration techniques were used..$^{[8]}$ Distal locking was applied without fluoroscopy, then a grooved tipped screw was placed in the head from the proximal oval hole. As the compression device contacted proximal lock screw, $1 \mathrm{~mm}$ compression was applied. When compression device was on the system, the full threaded cortical screw was placed bicortically. The compression device was removed and the compression screw was placed so that there was no loosening of the proximal screw. Finally, the end cup was put into place and the procedure was completed. The rotator cuff for entry was repaired and the interstages were closed properly.

After the contact of compression apparatus and the screw in the oval hole, it was turned in one circuit and a compression of $1 \mathrm{~mm}$ was formed in the fracture line, which was designed on the same principle as the dynamic compressive plate (DCP), with $1 \mathrm{~mm}$ compression applied to the fracture line. ${ }^{[9]}$

Finite element (FE) modeling and analyses were performed by using ANSYS $^{\circledR} 16.2$ (NASDAQ: ANSS). The FE model of bone, intrameduller compressive nail (ICN), and screws were constructed. The material properties assigned to the bone, titanium ICN, and screws were summarized in Table I.

As a result of the finite element analysis for the humerus screw that we used, the strain distribution at Figure 5 was obtained. An examination of this stress distribution showed that the stress values were between $10.9 \mathrm{MPa}$ and $89 \mathrm{MPa}$. An examination of the distribution of stress values obtained revealed that the load distribution at the fracture sections formed by the One millimeter displacement value applied by the nail screw appeared to be the result of moment and axial force. The mean stress was approximately $50 \mathrm{MPa}$.

\section{Statistical analysis}

Descriptive statistics were presented as "mean \pm standard deviation" and " $\mathrm{n}(\%)$ " values. Spearman correlation test was performed to test the relationships in quantitative variables with non-normal distribution. Statistical analysis was performed using the computer software Statistical Package for Social Sciences (IBM SPSS Statistics for Windows, version 21.0. released 2012, IBM Corp.,
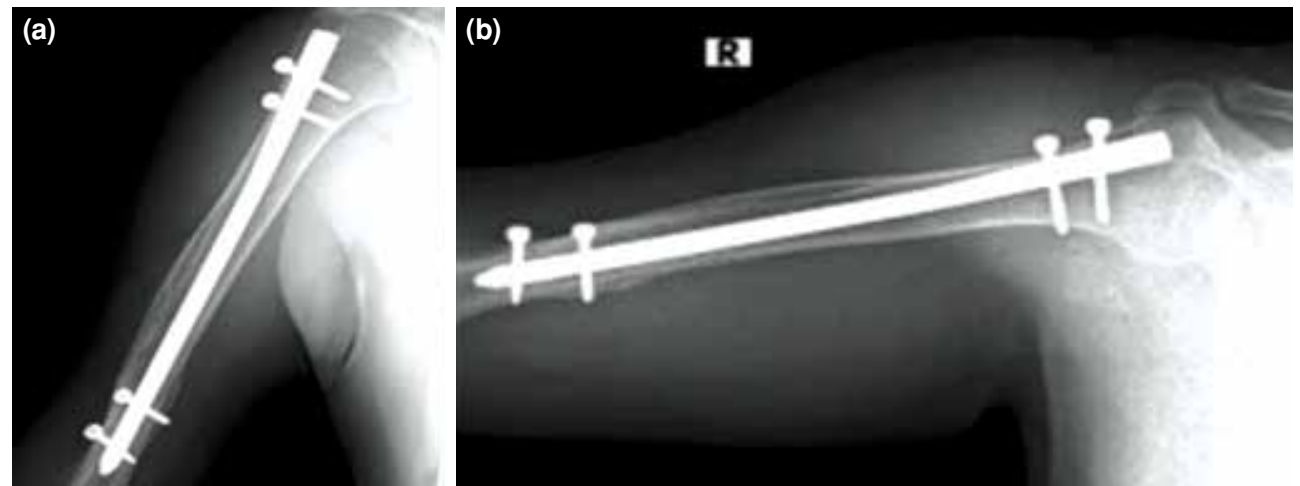

Figure 2. Postoperative 12-month (a) anteroposterior and (b) lateral radiographs. 

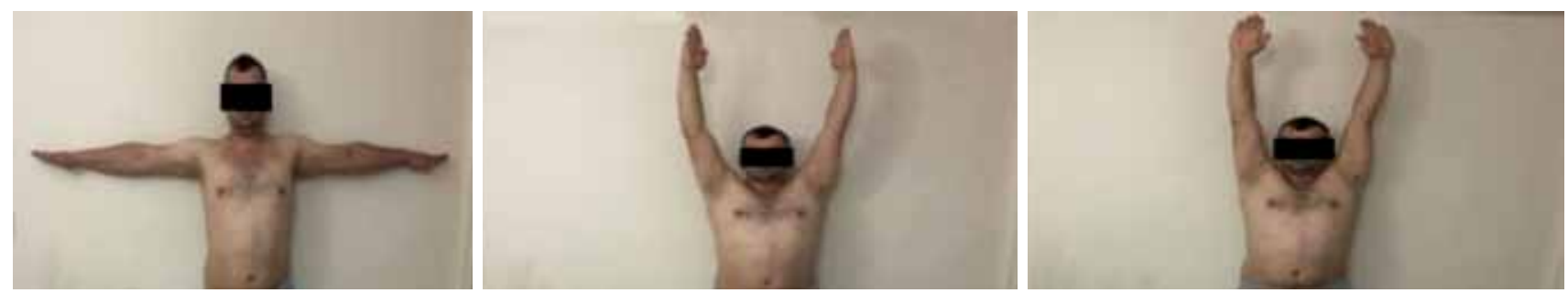

Figure 3. Functional result of same patient at postoperative first year.

Armonk, NY, USA). A $p$ value of $<0.05$ was considered statistically significant. Patient characteristics were described in Table II.

\section{RESULTS}

Full bone union was achieved in all patients at mean 14.8 weeks (range 12 to 17 weeks). No angulation to create a problem was observed functionally or radiologically in any patient. Using the ConstantMurley shoulder functional scoring system, the mean postoperative score was 90 (range 72 to 100). There was a statistically significant, negative and strong correlation between union time and the ConstantMurley score $(\mathrm{r}=-0.78, \mathrm{p}<0.001)$ (Figure 6). In two of the patients, the nail was observed to remain high. In one of these patients, findings of impingement were observed. Immediately after the union was achieved, the nail was removed and the complaints of the patient resolved. In the other patient, although the nail remained high, there was no shoulder problem. In one patient where open reduction was applied and radial nerve damage developed, all functions returned to the normal in approximately four months. No problems such as vascular injury or infection were encountered in any patient.

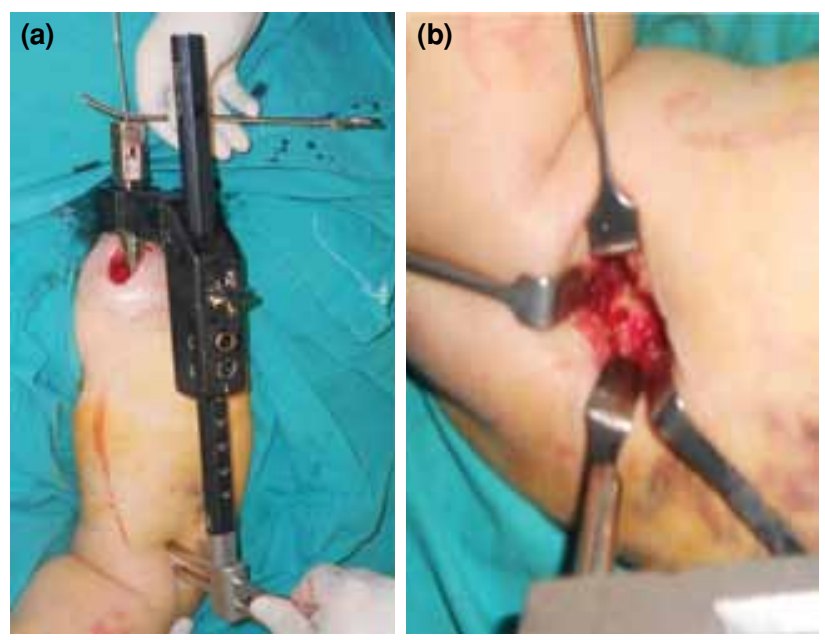

Figure 4. (a, b) Intraoperative distal locking without fluoroscopy.

\section{DISCUSSION}

Functional brace treatment is the gold standard in the conservative treatment of humerus shaft fractures. ${ }^{[10]}$ Still, it has the disadvantages of high rates of malunion and nonunion. ${ }^{[11]}$ Surgical treatment significantly decreases the rates of malunion and nonunion, but there is no difference in terms of infection and radial nerve damage..$^{[12]}$ Open reduction plating and IMN are the most accepted methods in the surgical treatment of humerus shaft fractures. There have been many controlled, randomized studies related to these two surgical methods. Each method has its own advantages and disadvantages. ${ }^{[13]}$ While high rates of union can be obtained with plate and screw fixation, there are disadvantages of greater soft tissue dissection and radial nerve damage ${ }^{[5]}$ It is possible to avoid these disadvantages with IMN. Biomechanically, IMN is stronger and it is possible to apply the method with less soft tissue dissection. ${ }^{[14]}$

There are few studies in the literature related to locked, compressive humerus nailing. ${ }^{[15]}$ To our knowledge, there is no study to evaluate the radiological and functional outcomes of a locked compressive intramedullary nail in adult humerus shaft fractures with compression in the literature. When IMN is applied appropriately, closed and compressive, the rate of union is at least as high as that of plate-screw and the possibility of soft tissue and neurovascular damage can be considered to be less than in plate-screw application..$^{[7]}$

In a study by Putti et al., ${ }^{[16]}$ plate screw and IMN were compared in 34 patients, with the application of IMN to 16 patients and plate screw to 18 patients. In one patient applied with plate screw and graft because of pseudarthrosis, superficial infection developed. In the group applied with IMN, nail breakage was observed in one patient, adhesive capsulitis in three, and a fracture in the tuberculum majus in one. No radial nerve damage was observed in either group. In the current study, no screw breakage, superficial infection, adhesive capsulitis or fracture of the tuberculum majus were seen in 
TABLE I

Mechanical properties of materials used in analyses

\begin{tabular}{lccr}
\hline Material & Density $\left(\mathrm{kg} / \mathrm{m}^{3}\right)$ & Elastic modulus $(\mathrm{GPa})$ & Poisson's ratio \\
\hline Titanium alloy (Ti6A14V) (ICN and screws) & 4440 & 106 & 0.2 \\
Cortical bone & 1800 & 17 & 0.3 \\
Trabecular bone & 300 & 2 & 0.4 \\
\hline
\end{tabular}

any patient. However, radial nerve symptoms were observed in one patient.

In another study by Yörükoğlu et al. ${ }^{[17]}$ where internal fixation was applied to 24 patients of humerus fractures with radial nerve palsy, the radial nerve recovery time was 12 weeks, while in our study, radial nerve recovery time was recorded as 16 weeks.

And in another study by Changulani et al., ${ }^{[18]}$ IMN was applied to 23 patients and DCP to 24 patients and the results were compared. Nonunion was determined in three patients of each group applied with IMN or DCP. With the exception of three patients in each group with nonunion, functionally all patients were able to return to work in six months. Functional results were determined as $85.7 \%$ in the IMN group and as $87.5 \%$ in the DCP group, with no statistically significant difference between the groups. Infections were to occur in a total of five patients in the DCP group as superficial in two cases and deep infection in three cases, all of which recovered with debridement and antibiotic treatment. In the group applied with IMN, deep infection developed in one patient, the nail was changed and union was achieved with bone graft. In the IMN group, impingement syndrome in the shoulder was determined in four patients and this problem was resolved with removal of the nail after bone union. In one patient in the IMN group, implant failure developed with breakage of the nail in the distal plane and axillary nerve damage developed.

In the current study, bone union was achieved in all the patients. The Constant-Murley score was

\section{TABLE II}

Patients' characteristics $(n=24)$

\begin{tabular}{lrrr}
\hline & $\mathrm{n}$ & $\%$ & Mean $\pm \mathrm{SD}$ \\
\hline Age (year) & & & $42 \pm 9.7$ \\
Gender & & & \\
$\quad$ Male & 12 & 50 & \\
$\quad$ Female & 12 & 50 & \\
Fracture union time (month) & & & $14.8 \pm 1.6$ \\
Constant-Murley score & & & $90 \pm 8.9$ \\
\hline
\end{tabular}

SD: Standard deviation. examined and the mean score was found to be 90 . No superficial or deep infection was determined. In one patient, impingement syndrome occurred because the nail remained high in the proximal and this problem was resolved with removal of the nail after the union. No implant failure was determined in any patient. No axillary nerve damage was encountered. Radial

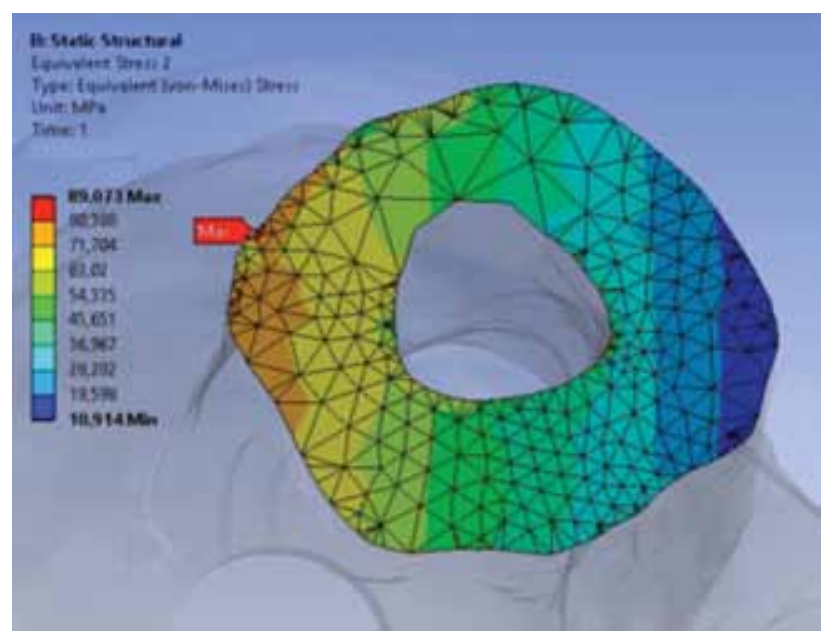

Figure 5. Finite element analysis, stresses on fracture site under $1 \mathrm{~mm}$ compression.

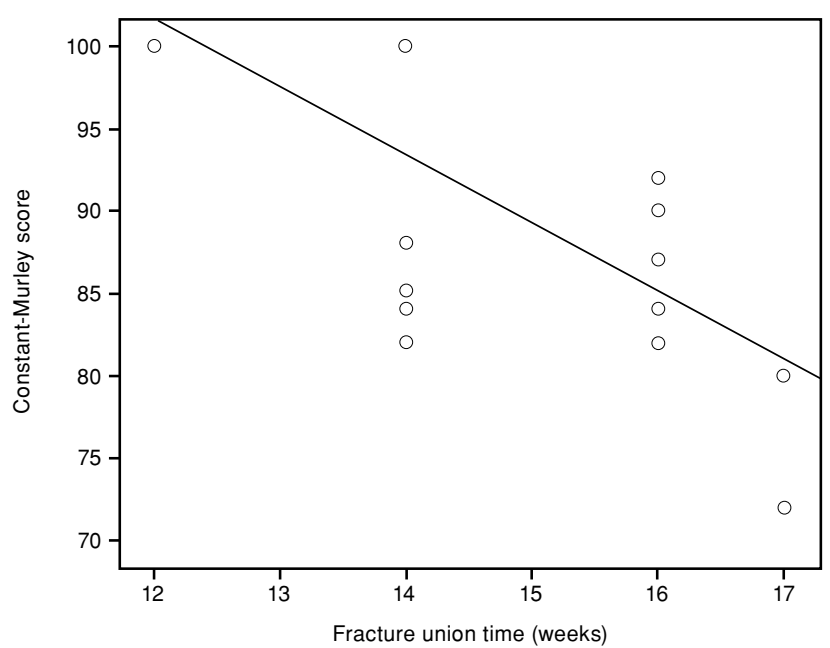

Figure 6. Relationship between duration of union and ConstantMurley score. 
nerve damage occurred in one patient where open nail application was performed and all functions recovered in four months.

In an experimental study of Baki et al., ${ }^{[19]}$ intramedullary compressive femoral nail was applied to rabbits femur, where compression accelerated fracture union and shortened fracture union time. In this study, it was stated that there was no radiologically significant difference in the mean of $34.5 \mathrm{MPa}$ in the first group and the mean of $88 \mathrm{MPa}$ in the second group but they were better in the $34.5 \mathrm{MPa}$ stress values when examined histopathologically. According to the finite analysis that we applied, the mean stress value was $50 \mathrm{MPa}$. This value was closer to that of the first group.

Moreover, Sahu et al. ${ }^{[20]}$ applied intramedullary locking nail to 78 patients with humerus shaft fractures and the time to fracture union was reported as mean 110 days (range 90 to 150 days). In another study, time to union was reported as mean 126 days (range 56 to 252 days). ${ }^{[21]}$ In the current study, the mean time to union was 103 days (range 84 to 120 days).

Li et al. ${ }^{[22]}$ compared patients applied with antegrade or retrograde IMN for humerus shaft fractures. Blood loss during surgery was observed to be less in the antegrade group and shoulder problems were naturally fewer in the retrograde group. No difference was determined between the groups in respect of operating time, complications and time to bone union. In the group applied with antegrade nailing, shoulder problems were reported in eight patients, nonunion in four patients and a radial nerve lesion in two patients. In the group applied with retrograde nailing, iatrogenic fracture was determined in three patients. As previously stated, in the current study, shoulder problems formed in one patient and a radial nerve lesion in another patient. No fracture union problems were encountered in any of the patients. The absence of union problems can be attributed to greater stability achieved by compression on the nail.

Limitations of this study include the wide age range of patients and the limited number of patients with a sufficient follow-up period.

In conclusion, compressive nailing is used to draw the fragments closer to each other. Due to the properties of the nails used in this study, evident stress was created in the fracture line with the apparatus and the compression screw together and there was a significant increase in stability. Locking compressive IMN in humerus fractures can be considered as a good treatment method, which can be preferred since it is more stable, it allows early movement and has high rates of union.

\section{Declaration of conflicting interests}

The authors declared no conflicts of interest with respect to the authorship and/or publication of this article.

\section{Funding}

The authors received no financial support for the research and/or authorship of this article.

\section{REFERENCES}

1. Schemitsch EH, Bhandari M. Fractures of the diaphyseal humerus. In: Browner BD, Jupiter. JB, Levine AM, Trafton PG, eds. Skeletal trauma, 3rd ed. Toronto: WB Saunders; 2001:1481-1511.

2. Sarmiento A, Zagorski JB, Zych GA, Latta LL, Capps CA. Functional bracing for the treatment of fractures of the humeral diaphysis. J Bone Joint Surg [Am] 2000;82:478-86.

3. Crenshaw HA. Fractures of shoulder, arm and forearm. In: Terry CS, editor. Campbell's operative orthopedics. Vol 3, 10th ed. St. Louis: Mosby; 2003. p. 2985-3069.

4. Gregory PR. Fracture of the humeral shaft. In: Bucholz RW, Heckman JD, editors. Rockwood and Green's fractures in adults. 5th ed. Philadelphia: Lippincott Williams \& Wilkins; 2001. p. 973-96.

5. Foster RJ, Dixon GL Jr, Bach AW, Appleyard RW, Green TM. Internal fixation of fractures and non-unions of the humeral shaft. Indications and results in a multi-center study. J Bone Joint Surg [Am] 1985;67:857-64.

6. Stannard JP, Harris HW, McGwin G Jr, Volgas DA, Alonso JE. Intramedullary nailing of humeral shaft fractures with a locking flexible nail. J Bone Joint Surg [Am] 2003;85:2103-10.

7. Baltov A, Mihail R, Dian E. Complications after interlocking intramedullary nailing of humeral shaft fractures. Injury 2014;45:9-15.

8. Aldemir C, Doğan A, İnci F, Sertkaya Ö, Duygun F. Distal locking techniques without fluoroscopy in intramedullar nailing. [Article in Turkish] Eklem Hastalik Cerrahisi 2014;25:64-9.

9. Ruedi TP, Murphy WM. AO Principles of Fracture Management. New York: Thieme; 2000. Translation editor; Ağuş H. Tedavisinde AO Kuralları. İstanbul: Nobel; 2006.

10. Clement ND. Management of Humeral Shaft Fractures; Non-Operative Versus Operative. Arch Trauma Res 2015;4:28013.

11. Ali E, Griffiths D, Obi N, Tytherleigh-Strong G, Van Rensburg L. Nonoperative treatment of humeral shaft fractures revisited. J Shoulder Elbow Surg 2015;24:210-4.

12. Mathis JM, DeNardo AJ, Jensen ME, Lin KY, Dion JE. Arteriovenous fistula of the scalp after hair transplantation treated by endovascular embolization. Ann Plast Surg 1994;33:633-7.

13. McCormack RG, Brien D, Buckley RE, McKee MD, Powell J, Schemitsch EH. Fixation of fractures of the shaft of the humerus by dynamic compression plate or intramedullary nail. A prospective, randomised trial. J Bone Joint Surg [Br] 2000;82:336-9.

14. Vennettilli M, Petrisor B, Athwal GS. Operative treatment of diaphyseal humeral fractures. J Hand Surg [Am] 
2011;36:905-6.

15. Virkus WV, Goldberg SH, Lorenz EP. A comparison of compressive force generation by plating and intramedullary nailing techniques in a transverse diaphyseal humerus fracture model. J Trauma 2008;65:103-8.

16. Putti AB, Uppin RB, Putti BB. Locked intramedullary nailing versus dynamic compression plating for humeral shaft fractures. J Orthop Surg (Hong Kong) 2009;17:139-41.

17. Yörükoğlu AÇ, Demirkan AF, Büker N, Akman A, Ok N. Humeral shaft fractures and radial nerve palsy: early exploration findings. Eklem Hastalik Cerrahisi 2016;27:41-5.

18. Changulani M, Jain UK, Keswani T. Comparison of the use of the humerus intramedullary nail and dynamic compression plate for the management of diaphyseal fractures of the humerus. A randomised controlled study.
Int Orthop 2007;31:391-5.

19. Baki ME, Aldemir C, Duygun F, Doğan A, Kerimoğlu G. Comparison of non-compression and compression interlocking intramedullary nailing in rabbit femoral shaft osteotomy model. Eklem Hastalik Cerrahisi 2017;28:7-12.

20. Sahu RL, Ranjan R, Lal A. Fracture union in closed interlocking nail in humeral shaft fractures. Chin Med J (Engl) 2015;128:1428-32.

21. Ozturkmen Y, Dogrul C, Dogan A, Karli M. Locked intramedullary nalling of humeral shaft fractures. [Article in Turkish] Ulus Travma Derg 2002;8:164-9.

22. Liu XH, Sun L, Jiang XY, Wang MY, Zhang LD. Comparison of the results of the treatment of humeral shaft fractures with antegrade locked intramedullary nailing and retrograde locked intramedullary nailing. Zhonghua Yi Xue Za Zhi 2007;87:902-5. 